\title{
Longitudinal changes in nutrient intakes in the Melbourne Chinese Cohort Study
}

\author{
Hua Zhang ${ }^{1, *}$, Bridget $\mathrm{H}-\mathrm{H}$ Hsu-Hage ${ }^{2}$ and Mark L Wahlqvist ${ }^{3}$ \\ 'Primary Health Branch, Department of Human Services Victoria, 2/555 Collins Street, Melbourne 3000, GPO Box \\ 3001, DX 210081, Australia: ${ }^{2}$ Department of Rural Health, Faculty of Medicine, Dentistry \& Health Sciences, The \\ University of Melbourne, PO Box 6500, Shepparton, Victoria 3632, Australia: ${ }^{3}$ International Health \& Development \\ Unit and Asia Pacific Health \& Nutrition Centre, Monash University, Wellington Road, Clayton, Melbourne, Victoria \\ 3168, Australia
}

Submited 13 September 2000: Accepted 20 August 2001

\begin{abstract}
Objective: To assess longitudinal changes in the consumption of nutrients and the impact of socio-economic factors on diet transition in the Melbourne Chinese Health Study (MCHS) cohort.

Design: Longitudinal study including two phases: baseline (1989/90) and follow-up (1995/97).

Settings: Melbourne metropolitan areas in Victoria, Australia.

Study subjects and method: Two hundred and sixty-two Chinese men and women aged 25 years and over, recruited at baseline, who had completed the both baseline and follow-up food-frequency questionnaires.

Results: Women increased their daily intakes of energy $(+549 \mathrm{~kJ})$, protein $(+7.8 \mathrm{~g})$, fat $(+7.3 \mathrm{~g})$ and dietary fibre $(+5.6 \mathrm{~g})$ whereas men decreased their daily consumption of carbohydrate $(-38.5 \mathrm{~g})$ over an average period of 8 years. Energy contributions from protein and fat rose while that from carbohydrate dropped for all cohort subjects. Increased intakes of riboflavin, $\beta$-carotene and iron were observed in men, while an increased consumption of thiamine, riboflavin, niacin and minerals (except sodium) was observed in women. Socio-economic factors such as education, family income levels and occupational categories appeared to have a far more powerful influence on changes in individual daily nutrient intakes than age or length of stay in Australia. Changes in nutrient intake in women were less affected by sociodemographic variables.

Conclusion: The observed changes in nutrient intakes indicated a progressive approach towards the Australian Recommended Dietary Intakes within this Chinese cohort population.
\end{abstract}

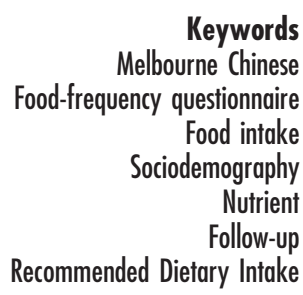

As part of an assessment of cardiovascular health in Melbourne Chinese, a long-term dietary intake study was initiated in 1988/89 ${ }^{1}$. Melbourne Chinese were found to have lower daily intakes of energy, fat, alcohol, some vitamins and minerals, especially calcium, compared with the wider Australian population ${ }^{2}$. The dietary habits of a population are dynamic; they change with migration and other secular trends ${ }^{3-5}$ and are often paralleled by transition in mortality rates, both total and disease-specific. Prospective studies have linked particular nutrients such as fat, cholesterol and alcohol to mortality and morbidity of so-called chronic non-communicable diseases like cardiovascular disease (CVD) and cancer ${ }^{6-9}$. Nutritional status reflects socio-economic status and accounts in part for the health profile of a population ${ }^{10}$. This report assesses the changes in nutrient intakes and their sociodemographic contributions in a Melbourne Chinese cohort over a period of about 8 years.

\section{Method}

\section{Subjects}

The baseline (BL) Melbourne Chinese Cohort Study was conducted in 1988-89 ${ }^{11}$. This study investigated food habits and risks for coronary heart disease. The recruitment method used in this study was based on telephone directory services and has been reported elsewhere ${ }^{12}$. Briefly, a set of Chinese surnames (in various dialects) was compiled from membership surname lists of several Chinese community organisations in Melbourne. A 
sampling list was then drawn from the 1988 Melbourne telephone directory listings of presumptive Chinese surnames. The study population was representative of Melbourne Chinese at the time of survey. Eligible subjects were individuals of Chinese ethnicity, aged 25 years and over with Australian citizenship or permanent resident status. Two hundred and sixty-two original cohort subjects completed the follow-up (FU) food-frequency questionnaire in 1995-1997. The average follow-up period was about 8 years.

\section{Dietary data collection}

Food intake was again estimated using the Melbourne Chinese food-frequency questionnaire ${ }^{13}$. All reference portions were determined using household measures such as a Chinese rice bowl, glass, teacup and other traditional cooking utensils and natural units (for example an apple). Subjects were asked to recall the frequency of consumption in terms of the number of times they ate the food per day, per week or per month for the past year. There were 266 food items in total in the follow-up study, 46 more items than at baseline, reflecting new food on the market. The daily food and nutrient intake values were calculated, the nutrient analysis being based on combined food composition tables from Australia ${ }^{14}$, $\mathrm{China}^{15}$ and other Asian countries ${ }^{16-17}$.

\section{Statistical analysis}

Nutrient intakes were expressed in $\mathrm{mg}, \mu \mathrm{g}$ or mmol per day. Analysis of variance (ANOVA) paired $t$-tests were used in the assessment of individual changes. Spearman correlation analysis was used to examine the relationships between longitudinal changes in dietary intakes and age, length of stay in Australia, household income, education level and occupational category. SAS /STAT software ${ }^{18}$ was applied in the data analysis. Significance of difference was set at the $5 \%$ level of probability.

\section{Results}

\section{Sociodemographic characteristics}

The average age of the follow-up subjects was $>50$ years, with men older than women. No significant changes in educational levels were found (Table 1). However, the proportions of lower family income level and home duty \& retired had increased significantly in both men and women. More than $50 \%$ of subjects had at least 12 years' education and over $40 \%$ of men and $33 \%$ of women had an annual family income greater than $\$ 40000$. The Melbourne Chinese men generally had more advanced sociodemographic status than did the women.

\section{Daily macronutrient intakes and changes}

For men, there was a decreased daily consumption of

Table 1 Differences in sociodemographic characteristics between BL and FU by gender

\begin{tabular}{|c|c|c|c|c|}
\hline & \multicolumn{2}{|c|}{ Men $(n=136)$} & \multicolumn{2}{|c|}{ Women $(n=126)$} \\
\hline & $\mathrm{BL}$ & FU & $\mathrm{BL}$ & FU \\
\hline Age (mean \pm SD) (years) & $45.6 \pm 10.6$ & $53.6 \pm 10.5^{\star \star \star}$ & $43.3 \pm 11.8$ & $51.3 \pm 11.8^{\star \star *}$ \\
\hline LOSIA (mean \pm SD) (years) & $13.5 \pm 8.9$ & $21.4 \pm 9.4^{\star \star \star}$ & $9.6 \pm 6.4$ & $18.4 \pm 9.3^{\star \star \star}$ \\
\hline Gender (\%) & \multicolumn{2}{|c|}{52} & \multicolumn{2}{|c|}{48} \\
\hline \multicolumn{5}{|l|}{ Country of birth (\%) } \\
\hline China \& Taiwan & \multicolumn{2}{|c|}{$31(22.8)$} & \multicolumn{2}{|c|}{$33(26.2)$} \\
\hline Hong Kong \& Macau & \multicolumn{2}{|c|}{$20(14.7)$} & \multicolumn{2}{|c|}{$14(11.1)$} \\
\hline Singapore \& Malaysia & \multirow{2}{*}{\multicolumn{2}{|c|}{$\begin{array}{l}42(30.9) \\
28(20.6)\end{array}$}} & \multicolumn{2}{|c|}{$35(27.8)$} \\
\hline Vietnam \& Cambodia & & & \multicolumn{2}{|c|}{$31(24.6)$} \\
\hline Australia \& other countries & \multicolumn{2}{|c|}{$\begin{array}{l}28(20.6) \\
15(11.0)\end{array}$} & \multicolumn{2}{|c|}{$13(10.3)$} \\
\hline \multicolumn{3}{|l|}{ Educational level (\%) } & & \\
\hline$<6$ years & $13(9.6)$ & $11(8.1)$ & $34(27.0)$ & $33(26.2)$ \\
\hline $7-9$ years & $24(17.7)$ & $25(18.4)$ & $22(17.5)$ & $22(17.5)$ \\
\hline $10-12$ years & $31(22.8)$ & $31(22.8)$ & $34(27.0)$ & $34(27.0)$ \\
\hline \multirow[t]{2}{*}{$>12$ years } & $68(50.0)$ & $69(50.7)$ & $36(28.6)$ & $37(29.4)$ \\
\hline & \multicolumn{2}{|c|}{$\chi^{2}=0.2, P>0.05$} & \multicolumn{2}{|c|}{$\chi^{2}=0.02, P>0.05$} \\
\hline \multicolumn{5}{|l|}{ Family income level (\%) } \\
\hline$<\$ 12000$ & $7(5.2)$ & $26(19.1)$ & $16(12.8)$ & $37(29.4)$ \\
\hline$\$ 12001-22000$ & $34(25.2)$ & $15(11.0)$ & $31(24.8)$ & 18 (14.3) \\
\hline$\$ 22001-40000$ & $38(28.2)$ & 33 (24.2) & $35(28.0)$ & $29(23.0)$ \\
\hline$>\$ 40000$ & $56(41.5)$ & $62(45.6)$ & $43(34.4)$ & 42 (33.3) \\
\hline & \multirow{2}{*}{\multicolumn{2}{|c|}{$\chi^{2}=19.0, P<0.001$}} & \multicolumn{2}{|c|}{$\chi^{2}=12.3, P<0.01$} \\
\hline \multicolumn{4}{|l|}{ Occupational category (\%) } & \\
\hline Professional \& administration & $40(29.4)$ & $59(43.4)$ & $34(27.0)$ & $33(26.2)$ \\
\hline Clerical \& sales & $35(25.7)$ & $12(8.8)$ & $24(19.1)$ & $14(11.1)$ \\
\hline Trades \& labour & $55(40.4)$ & $49(36.0)$ & $37(29.4)$ & $28(22.2)$ \\
\hline \multirow{2}{*}{ Home duty \& retired } & $6(4.4)$ & $16(11.8)$ & $31(24.6)$ & $51(40.5)$ \\
\hline & \multicolumn{2}{|c|}{$\chi^{2}=19.7, P<0.001$} & \multicolumn{2}{|c|}{$\chi^{2}=8.7, P<0.05$} \\
\hline
\end{tabular}

SD - standard deviation.

${ }^{\star \star \star} P<0.001 ;$ t-test. 
Table 2 Daily intakes of macronutrients and changes (FU-BL) by gender

\begin{tabular}{|c|c|c|c|c|c|c|}
\hline & \multicolumn{3}{|c|}{ Men $(n=136)$} & \multicolumn{3}{|c|}{ Women $(n=126)$} \\
\hline & $\begin{array}{c}\mathrm{FU} \\
\text { Mean } \pm \mathrm{SE}\end{array}$ & $\begin{array}{c}\mathrm{BL} \\
\text { Mean } \pm \mathrm{SE}\end{array}$ & $\begin{array}{c}\text { Paired (FU-BL) } \\
\Delta \text { Mean } \pm \text { SE }\end{array}$ & $\begin{array}{c}\text { FU } \\
\text { Mean } \pm S E\end{array}$ & $\begin{array}{c}\mathrm{BL} \\
\text { Mean } \pm S E\end{array}$ & $\begin{array}{c}\text { Paired (FU-BL) } \\
\Delta \text { Mean } \pm \text { SE }\end{array}$ \\
\hline Energy (kJ) & $7803 \pm 165$ & $8549 \pm 388$ & $-745 \pm 386$ & $7578 \pm 186$ & $7029 \pm 214$ & $549 \pm 240 \dagger$ \\
\hline Protein (g) & $82.9 \pm 2.1$ & $81.7 \pm 3.1$ & $1.22 \pm 3.4$ & $79.7 \pm 2.2^{*}$ & $71.8 \pm 2.5$ & $7.84 \pm 3.0 \dagger \dagger$ \\
\hline Carbohydrate (g) & $253.7 \pm 6.0^{\star *}$ & $292.2 \pm 13.1$ & $-38.5 \pm 12.7 \dagger \dagger \dagger$ & $252.9 \pm 6.9$ & $241.5 \pm 7.3$ & $11.4 \pm 9.0$ \\
\hline Total fat (g) & $52.4 \pm 1.6$ & $54.0 \pm 5.9$ & $-1.58 \pm 6.0$ & $51.9 \pm 1.7^{\star *}$ & $44.6 \pm 1.8$ & $7.34 \pm 2.1 \dagger+\dagger$ \\
\hline Cholesterol (mg) & $229.8 \pm 9.5$ & $233.2 \pm 10.8$ & $-3.44 \pm 11.8$ & $219.4 \pm 11.5$ & $221.6 \pm 11.1$ & $-2.19 \pm 15.6$ \\
\hline Alcohol (g) & $4.9 \pm 1.0$ & $5.7 \pm 0.9$ & $-0.72 \pm 1.0$ & $1.0 \pm 0.2$ & $0.4 \pm 0.0$ & $0.48 \pm 0.3$ \\
\hline Fibre $(\mathrm{g})$ & $22.1 \pm 0.9$ & $20.4 \pm 1.3$ & $1.76 \pm 1.5$ & $23.1 \pm 0.8^{\star \star \star}$ & $17.5 \pm 0.6$ & $5.60 \pm 0.8 \dagger \dagger \dagger$ \\
\hline
\end{tabular}

SE - standard error.

${ }^{*}, P<0.05$; ${ }^{* *}, P<0.01$; ${ }^{* * *}, P<0.001$; cross-sectional comparison.

†, $P<0.05$; ††, $P<0.01$; ††, $P<0.001$; paired comparison.

carbohydrate in both cross-sectional and paired comparison (Table 2). For women, increased daily intakes of protein, fat and dietary fibre were found in both the crosssectional and paired comparisons, whereas energy intake increased by paired comparison only.

Significant differences between men and women were the changes in total energy, carbohydrate and dietary fibre consumption. Age and length of stay in Australia (LOSIA) did not affect macronutrient intake significantly. Table 3 also shows that changes in individual macronutrient intakes in women were not associated with sociodemographic status. However, in men, changes in intakes of protein, fat and cholesterol were negatively associated with education and family income level, and positively correlated with occupational category $(1=$ professional, $2=$ clerical \& sales, $3=$ trades \& labour, $4=$ home duty \& retired).

\section{Energy contribution and changes}

Figure 1a shows that the total energy intakes contributed by protein, fat and carbohydrate were about 18\%, 25\% and $55 \%$ for men and women, respectively, while men had higher percentage of energy from alcohol. Energy derived from protein and fat increased significantly over 8 years (Fig. 1b), while that from carbohydrate decreased in men. In women the same pattern was observed except that their energy intake from protein did not change. The main food sources of energy intake were cereal and cereal-based products (43\%), followed by meat, poultry and game (15\%).

The ratios of monounsaturated to saturated fatty acid $(\mathrm{M} / \mathrm{S})$ and polyunsaturated to saturated fatty acid $(\mathrm{P} / \mathrm{S})$ remained unchanged in both men $(\mathrm{M} / \mathrm{S}=1.08 \pm 0.02$, $\mathrm{P} / \mathrm{S}=0.41 \pm 0.02$ in both FU and $\mathrm{BL})$ and women $(\mathrm{M} / \mathrm{S}=$ $1.03 \pm 0.02, \mathrm{P} / \mathrm{S}=0.40 \pm 0.02$ for $\mathrm{FU}$ and $\mathrm{M} / \mathrm{S}=1.04 \pm$ $0.01, \mathrm{P} / \mathrm{S}=0.40 \pm 0.01$ for $\mathrm{BL})$.

\section{Daily micronutrient intakes and changes}

Table 4 presents the changes in micronutrient intakes for both men and women between the baseline and follow-up studies. In women, consumption of all micronutrients was increased significantly except for sodium, retinol, $\beta$ carotene and vitamin $\mathrm{C}$. In men, intakes of iron, riboflavin and $\beta$-carotene increased significantly.

Changes in the daily intake of potassium, calcium, phosphorus, magnesium and riboflavin were greater in women than in men (Fig. 2). Age was positively associated with changes in daily intakes of $\beta$-carotene $(r=0.20$, $P<0.05)$ and vitamin $\mathrm{C}(r=0.17, P<0.05)$ in men, while LOSIA was negatively related to intake of $\beta$-carotene $(r=-0.17, P<0.05)$ in women.

Table 5 shows that the Spearman correlation coefficients

Table 3 Correlation coefficients for changes in daily macronutrient intakes and socio-economic variables adjusted for age

\begin{tabular}{|c|c|c|c|c|c|c|}
\hline \multirow[b]{2}{*}{ Change in intake } & \multicolumn{3}{|c|}{ Men $(n=136)$} & \multicolumn{3}{|c|}{ Women $(n=126)$} \\
\hline & EDU & $\mathrm{FIC}$ & OCCP & EDU & FIC & OCCP \\
\hline Energy (kJ) & -0.16 & -0.05 & 0.13 & -0.15 & -0.10 & 0.13 \\
\hline Protein $(\mathrm{g})$ & $-0.26^{\star *}$ & $-0.17^{\star}$ & $0.25^{\star \star}$ & -0.14 & -0.01 & 0.002 \\
\hline Carbohydrate (g) & 0.02 & 0.04 & -0.04 & -0.08 & -0.13 & 0.15 \\
\hline Total fat $(\mathrm{g})$ & $-0.34^{\star \star \star}$ & $-0.26^{\star \star}$ & $0.32^{\star \star \star}$ & -0.10 & 0.04 & 0.03 \\
\hline Cholesterol (mg) & $-0.35^{\star \star \star}$ & $-0.23^{\star *}$ & $0.29^{\star \star \star}$ & -0.14 & 0.03 & -0.02 \\
\hline Alcohol (g) & 0.02 & $0.18^{\star}$ & -0.02 & 0.03 & 0.09 & -0.06 \\
\hline Fibre $(\mathrm{g})$ & -0.12 & -0.13 & 0.08 & -0.04 & -0.10 & 0.09 \\
\hline
\end{tabular}

EDU - education level; FIC - family income; OCCP - occupation categories (ascendant from professional, clerical \& sales, trades \& labour and home duty $\&$ retired).

${ }^{*}, P<0.05 ;{ }^{* \star}, P<0.01 ;{ }^{* \star}, P<0.001$ 


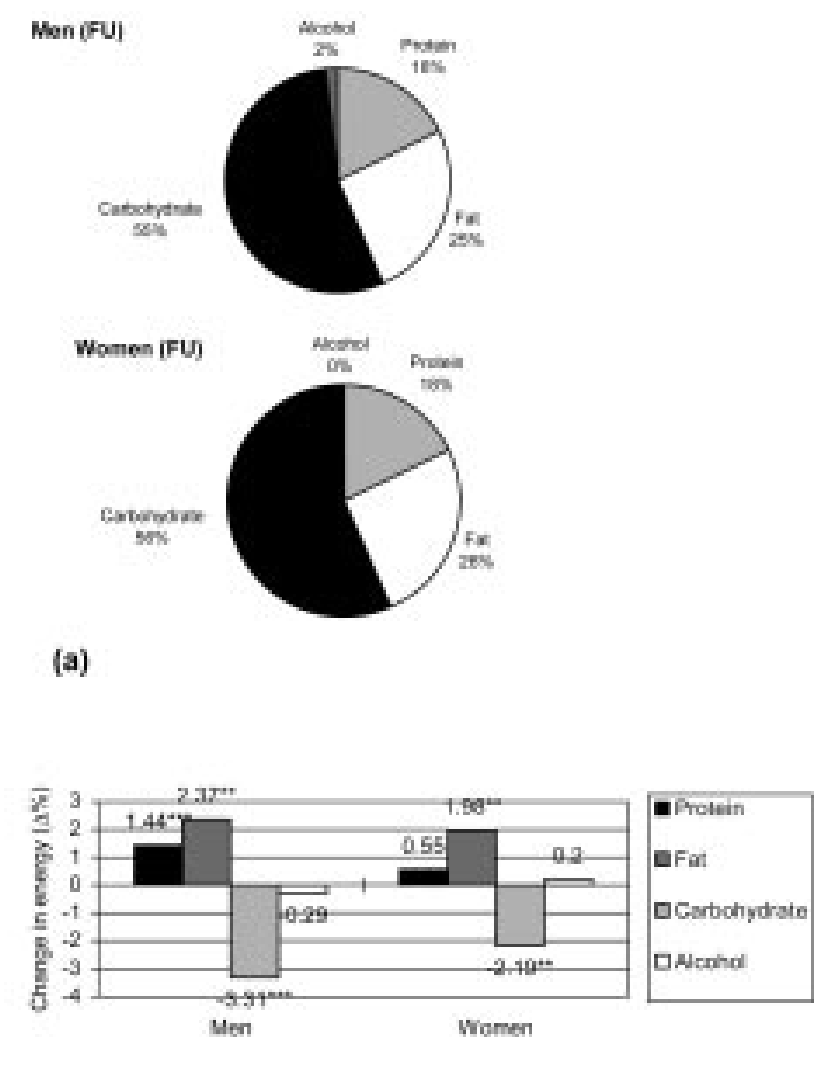

(b)

Fig. 1 (a) Energy contribution from macronutrients in follow-up study by gender; (b) paired individual changes $(\Delta \%)$ of energy derived from protein, fat, carbohydrate and alcohol in men and women $\left({ }^{*}, P<0.05 ;{ }^{* *}, P<0.01 ;{ }^{* \star *}, P<0.001\right)$

for the changes in daily micronutrient intakes were related to socio-economic factors, defined as education level, family income and occupational category. There were no relationships found in women. In men, education and family income level were negatively associated with the changes. Positive relationships between the micronutrient intake changes and occupational category were found.

\section{Comparison of daily nutrient intake between Melbourne Chinese cobort study and wider Australian population}

Melbourne Chinese women had average higher daily intake levels of energy, protein, carbohydrate, dietary fibre, vitamin $\mathrm{C}$, potassium, iron and zinc, whereas men had overall lower average daily nutrient intakes except for potassium, than their Australian counterparts ${ }^{19}$. The energy derived from carbohydrate was higher but that from fat was lower in Melbourne Chinese than in the wider Australian community. There was a significantly lower level of calcium intake in the Melbourne Chinese compared with the Australians. However, certain concerns need to be taken into account regarding these differences between the Melbourne Chinese and the wider Australian community, such as different dietary methods and body sizes.

\section{Assessment of adequacy in daily nutrient intake}

Based on Australian Dietary Guidelines (DG) or Recommended Dietary Intakes (RDIs) ${ }^{20}$, intakes of carbohydrate, fat, cholesterol and alcohol in Melbourne Chinese fulfilled the recommendations (Table 6). The average level of daily dietary fibre intake was below that recommended while protein intake was 1.5 times higher than the recommended for both men and women. The daily intakes of vitamin A, riboflavin, phosphorus and iron in women and niacin in men achieved the RDI requirement as a result of the significant increase in intake levels for these micronutrients. However, even with substantial increases in daily intakes of micronutrients in the FU phase, the average daily intake levels for calcium, magnesium and zinc were still lower than the Australia RDI for both men and women, as were vitamin A and riboflavin intakes for men.

\section{Discussion}

The magnitude of differences in diet was found to be greater amongst Asian immigrants than in other migrant populations ${ }^{19,21}$. This may be partly because of increased migration recently from countries such as Vietnam, Hong Kong and China. This was confirmed in the previous study of our Chinese cohort, and the differences remain even after 8 years. Gender differences in this cohort study were inconsistent, as in other studies of Australian immigrants $^{2,19,21-23}$. In general, Melbourne Chinese women experienced greater changes than their male counterparts.

There were notable increased contributions from protein and fats, and a concomitant decreased contribution from carbohydrate to total energy intake. The relative energy contributions from all other macronutrients remained within the healthy range. Compared with urban Beijing Chinese ${ }^{24}$ and Hong Kong Chinese ${ }^{25}$, Melbourne Chinese consumed much less fat (25\% vs. 33\% and 29\%, respectively) in their diet. Similarly, Melbourne Chinese maintained a high intake of carbohydrate and a low intake of fat compared with the wider Australian population. Plant-based foods in the Chinese diet made a significant contribution in this circumstance.

Significant increases in the intakes of iron, phosphorus and riboflavin in women improved overall micronutrient intake adequacy: the daily intake of retinol equivalents was within the safe range of RDI according to FAO/WHO $(1989)^{26}$ although lower than the Australian RDI target. The difference in retinol intake may be explained by the lack of dairy products such as milk and cheese eaten by this Chinese cohort.

The low intakes of vitamin A, calcium and zinc were phenomena observed not only in the present cohort, but also in numerous other Chinese populations ${ }^{27-29}$. Even so, there was an increase from baseline in Melbourne Chinese women but daily calcium intake was still below the Australian RDI. The traditional non-consumption of 
Table 4 Daily micronutrient intakes and changes (FU-BL) by gender

\begin{tabular}{|c|c|c|c|c|c|c|}
\hline & \multicolumn{3}{|c|}{$\operatorname{Men}(n=136)$} & \multicolumn{3}{|c|}{ Women $(n=126)$} \\
\hline & $\begin{array}{c}\text { FU } \\
\text { Mean } \pm \text { SE }\end{array}$ & $\begin{array}{c}\mathrm{BL} \\
\text { Mean } \pm S E\end{array}$ & $\begin{array}{c}\text { Paired changes } \\
\text { (FU-BL) } \\
\Delta \text { Mean } \pm \mathrm{SE}\end{array}$ & $\begin{array}{c}\text { FU } \\
\text { Mean } \pm \text { SE }\end{array}$ & $\begin{array}{c}\mathrm{BL} \\
\text { Mean } \pm S E\end{array}$ & $\begin{array}{c}\text { Paired changes } \\
\text { (FU-BL) } \\
\Delta \text { Mean } \pm S E\end{array}$ \\
\hline Sodium (mmol) & $66.4 \pm 2.7$ & $64.3 \pm 3.2$ & $2.11 \pm 3.4$ & $61.8 \pm 2.4$ & $58.2 \pm 2.4$ & $3.58 \pm 2.9$ \\
\hline Potassium (mmol) & $62.3 \pm 1.6$ & $61.9 \pm 2.7$ & $0.44 \pm 2.6$ & $63.9 \pm 2.1^{*}$ & $56.7 \pm 2.1$ & $7.22 \pm 2.1 \dagger \dagger \dagger$ \\
\hline Calcium (mg) & $487 \pm 17.8$ & $468 \pm 26.1$ & $20.11 \pm 28.3$ & $565 \pm 23.8^{\star * *}$ & $447 \pm 20.0$ & $118 \pm 26.9+\dagger \dagger$ \\
\hline Phosphorus (mg) & $1081 \pm 27.7$ & $1100 \pm 52.6$ & $-19.95 \pm 54.8$ & $1081 \pm 31.4^{\star \star}$ & $951 \pm 33.0$ & $131 \pm 39.5 \dagger †$ \\
\hline Magnesium (mg) & $260 \pm 6.0$ & $279 \pm 15.8$ & $-18.84 \pm 15.4$ & $254 \pm 7.3^{*}$ & $231 \pm 6.9$ & $22.12 \pm 7.9 \dagger \dagger$ \\
\hline Iron (mg) & $14.6 \pm 0.4^{\star \star \star}$ & $11.7 \pm 0.4$ & $2.95 \pm 0.5 \dagger \dagger \dagger$ & $14.7 \pm 0.5^{\star \star \star}$ & $10.6 \pm 0.4$ & $4.15 \pm 0.5 \dagger \dagger \dagger$ \\
\hline Zinc (mg) & $10.8 \pm 0.3$ & $10.0 \pm 0.4$ & $0.76 \pm 0.4$ & $10.3 \pm 0.3^{\star \star *}$ & $8.5 \pm 0.3$ & $1.73 \pm 0.4 \dagger \dagger \dagger$ \\
\hline Retinol $(\mu \mathrm{g})$ & $262 \pm 32.4$ & $299 \pm 30.6$ & $-36.76 \pm 39.4$ & $385 \pm 107$ & $322 \pm 38.9$ & $63 \pm 115$ \\
\hline$\beta$-Carotene $(\mu \mathrm{g})$ & $1973 \pm 107^{\star *}$ & $1581 \pm 92.2$ & $393 \pm 130 \dagger \dagger$ & $2393 \pm 134$ & $2062 \pm 166$ & $330 \pm 197$ \\
\hline Thiamine (mg) & $1.1 \pm 0.03$ & $1.0 \pm 0.03$ & $0.10 \pm 0.05$ & $1.2 \pm 0.04^{* * *}$ & $0.9 \pm 0.02$ & $0.22 \pm 0.05 \dagger \dagger \dagger$ \\
\hline Riboflavin (mg) & $1.4 \pm 0.04^{\star \star \star}$ & $1.1 \pm 0.04$ & $0.27 \pm 0.06 \dagger+\dagger$ & $1.6 \pm 0.06^{\star \star \star}$ & $1.1 \pm 0.1$ & $0.50 \pm 0.07 \dagger \dagger \dagger$ \\
\hline Vitamin C (mg) & $114 \pm 5.3$ & $113 \pm 6.1$ & $1.48 \pm 6.8$ & $133 \pm 6.4$ & $121.1 \pm 7.0$ & $11.59 \pm 7.2$ \\
\hline Niacin (mg) & $17.7 \pm 0.4$ & $17.4 \pm 0.7$ & $0.28 \pm 0.7$ & $16.3 \pm 0.5$ & $15.0 \pm 0.5$ & $1.23 \pm 0.6 \dagger$ \\
\hline
\end{tabular}

SE - standard error.

${ }^{\star}, P<0.05$; ${ }^{\star *}, P<0.01$; ${ }^{* \star}, P<0.001$; cross-sectional comparison.

†, $P<0.05$; †, $P<0.01$; ††, $P<0.001$; paired comparison.

dairy products in Chinese food culture may be the main contributor to their low calcium intake. A genetic variation in the metabolism of bone mineral has been reported in a comparative study of Asian and Caucasians ${ }^{30}$ and of blacks and whites ${ }^{31}$. Body calcium retention by Chinese may differ from their Australian host population. Therefore, use of the Australian calcium RDI may not be appropriate for ethnic Chinese immigrants.

Socio-economic status distinguishes groups not only in terms of income, educational level and occupational category, but also in respect of attitudes and behaviours such as dietary habits ${ }^{21}$. Sociodemographic differences in diet also change with time ${ }^{32}$. Despite the greater changes in individual dietary nutrient intakes observed in women, the socio-economic influence on changes in dietary nutrient intake was far greater in men than in women. The influence of length of stay in Australia on change in nutrient intakes is reduced or has ceased, as have food acculturation and food variety since the baseline study. Age was found to be positively associated with changes in intake of $\beta$-carotene and vitamin $C$ in men. Men who were highly educated or financially advanced had reduced intakes of protein, fats and cholesterol. The Hong Kong Dietary and Cardiovascular Risk Prevalence study showed a similar association between higher education level and healthier $\operatorname{diet}^{33}$. Occupational category influenced men

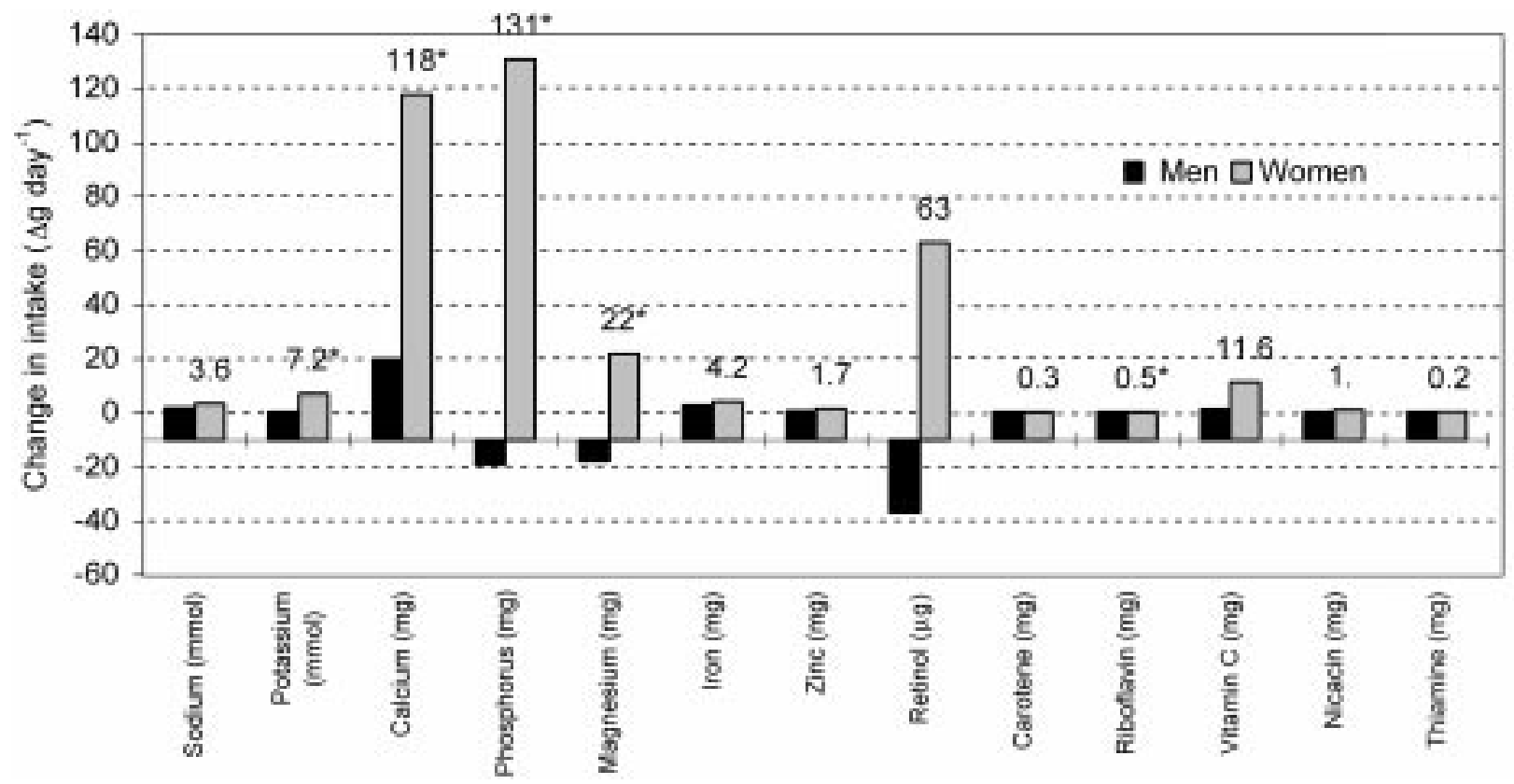

Fig. 2 Gender differences in changes in micronutrients intake $\left(\Delta \mathrm{g} \mathrm{day}^{-1}\right)\left({ }^{*}, P<0.05 ;{ }^{* *}, P<0.01 ;{ }^{* \star *}, P<0.001\right)$ 
Table 5 Spearman correlation coefficients for changes in daily micronutrient intakes and socio-economic variables adjusted for age

\begin{tabular}{|c|c|c|c|c|c|c|}
\hline \multirow[b]{2}{*}{ Change in intake } & \multicolumn{3}{|c|}{ Men $(n=136)$} & \multicolumn{3}{|c|}{ Women $(n=126)$} \\
\hline & EDU & FIC & $\mathrm{OCCP}$ & EDU & FIC & OCCP \\
\hline Sodium (mmol) & $-0.26^{\star *}$ & $-0.22^{\star \star}$ & $0.30^{* * *}$ & -0.11 & -0.03 & 0.15 \\
\hline Potassium (mmol) & $-0.31^{\star \star \star}$ & $-0.27^{\star \star}$ & $0.23^{\star \star}$ & -0.02 & -0.003 & 0.05 \\
\hline Calcium (mg) & $-0.32^{\star \star *}$ & $-0.23^{\star *}$ & $0.32^{* * *}$ & 0.11 & 0.06 & 0.003 \\
\hline Phosphorus (mg) & $-0.32^{\star \star \star}$ & $-0.19^{\star}$ & $0.29^{\star \star \star}$ & -0.05 & -0.01 & 0.006 \\
\hline Iron (mg) & $-0.17^{\star}$ & $-0.18^{*}$ & $0.18^{\star}$ & -0.02 & -0.02 & 0.05 \\
\hline Retinol $(\mu \mathrm{g})$ & $-0.18^{\star}$ & -0.14 & $0.19^{*}$ & -0.10 & -0.02 & 0.18 \\
\hline Thiamine (mg) & $-0.19^{\star}$ & -0.12 & $0.17^{*}$ & 0.05 & -0.03 & 0.07 \\
\hline Riboflavin (mg) & $-0.29^{\star \star \star}$ & $-0.23^{\star *}$ & $0.32^{* * *}$ & -0.05 & 0.03 & 0.01 \\
\hline Vitamin C (mg) & $-0.20^{\star}$ & $-0.24^{\star \star}$ & $0.20^{*}$ & -0.05 & -0.07 & 0.15 \\
\hline$\beta$-Carotene $(\mu \mathrm{g})$ & $-0.19^{\star}$ & -0.11 & 0.13 & 0.09 & -0.07 & 0.04 \\
\hline
\end{tabular}

EDU - education level; FIC - family income; OCCP - occupation categories (ascendant from professional, clerical \& sales, trades \& labour and home duty \& retired).

${ }^{*}, P<0.05 ;{ }^{* *}, P<0.01 ;{ }^{* * *}, P<0.001$.

more than women since more than $40 \%$ of women were engaged in home duty or were retired. Practice in the Australian workforce has given Chinese Australians little option to maintain a traditional Chinese diet unlike those in China and Hong Kong, where take-away foods and packed lunches cater for the Chinese diet. Occupation also has a significant contribution to the food acculturation in this study population ${ }^{34}$.

On the whole, nutritional intake in this cohort has improved the fulfilment of the Australian RDIs or
Guidelines since 1988/89 and their cardiovascular health status remains ${ }^{35}$. Reducing the speed of food acculturation for newly immigrated Chinese may be a beneficial health promotion to achieve optimised protection from Westernised disease burdens.

\section{Conclusion}

Melbourne Chinese have passed the rapid transition phase in their dietary intake. The nutrient intakes in the follow-up

Table 6 Nutrient intake adequacies according to Australian Dietary Guidelines or RDI in men and women

\begin{tabular}{|c|c|c|c|c|c|}
\hline \multirow[b]{2}{*}{ Nutrient } & \multirow{2}{*}{$\begin{array}{l}\text { Australian } \\
\mathrm{DG} / \mathrm{RDI}^{20}\end{array}$} & \multicolumn{2}{|c|}{ Men (FU) } & \multicolumn{2}{|c|}{ Women (FU) } \\
\hline & & Mean intake & Adequate & Mean intake & Adequate \\
\hline \multicolumn{6}{|l|}{ Macronutrients } \\
\hline Protein $(g)$ & $\begin{array}{l}\text { Men: } 55 \\
\text { Women: } 45\end{array}$ & 83 & レ & 80 & $レ$ \\
\hline Carbohydrate (as \% of energy) & $>50$ & 54.7 & $\boldsymbol{\nu}$ & 55.9 & $\boldsymbol{\nu}$ \\
\hline Total fat (as \% of energy) & $<30$ & 25.2 & $\boldsymbol{\nu}$ & 25.6 & $\boldsymbol{}$ \\
\hline Saturated fat (as \% of energy) & $<10$ & 10.4 & $\cong$ & 10.7 & $\cong$ \\
\hline Monounsaturated fat (as \% of energy) & 10 & 10.7 & $\cong$ & 10.7 & $\cong$ \\
\hline Polyunsaturated fat (as \% of energy) & $6-7$ & 4.0 & $x$ & 4.0 & $x$ \\
\hline Dietary cholesterol (mg) & $300 ?$ & 230 & $\boldsymbol{\nu}$ & 219 & $\boldsymbol{}$ \\
\hline Alcohol (as \% of energy) & $<5$ & 1.7 & レ & 0.4 & $\boldsymbol{\nu}$ \\
\hline Dietary fibre $(\mathrm{g})$ & 30 & 22.1 & $\times$ & 23.1 & $x$ \\
\hline \multicolumn{6}{|l|}{ Micronutrients } \\
\hline Vitamin A (retinol equivalents) $(\mu \mathrm{g})$ & 750 & 592 & $x$ & 775 & $\boldsymbol{}$ \\
\hline Thiamine (mg) & $\begin{array}{l}\text { Men: } 0.9 \\
\text { Women: } 0.8\end{array}$ & 1.1 & レ & 1.2 & レ \\
\hline Riboflavin (mg) & $\begin{array}{l}\text { Men: } 1.7 \\
\text { Women: } 1.2\end{array}$ & 1.4 & $\times$ & 1.6 & $\uparrow$ \\
\hline Niacin (niacin equivalents) (mg) & $\begin{array}{l}\text { Men: } 19 \\
\text { Women: } 13\end{array}$ & 31 & レ & 29 & レ \\
\hline Vitamin C (mg) & $\begin{array}{l}\text { Men: } 40 \\
\text { Women: } 30\end{array}$ & 114 & レ & 132 & レ \\
\hline Potassium (mmol) & $50-140$ & 62 & レ & 64 & $\boldsymbol{}$ \\
\hline Calcium (mg) & 800 & 487 & $\times$ & 565 & $x$ \\
\hline Phosphorus (mg) & 1000 & 1081 & $\boldsymbol{\nu}$ & 1081 & $\boldsymbol{}$ \\
\hline Magnesium (mg) & $\begin{array}{l}\text { Men: } 320 \\
\text { Women: } 270\end{array}$ & 260 & レ & 254 & $\times$ \\
\hline Iron (mg) & $\begin{array}{l}\text { Men: } 7 \\
\text { Women:12-16 }\end{array}$ & 15 & レ & 15 & レ \\
\hline Zinc (mg) & 12 & 11 & $\cong$ & 10 & $x$ \\
\hline
\end{tabular}


phase indicate a significant improvement in dietary quality compared with the baseline phase. It is remarkable that the contribution of fat to total energy intake in Melbourne Chinese was not only just below that of their host population, but also was far less than that of their ethnic counterparts. Overall, the nutritional intake pattern has improved over the last 8 years. The insufficient intake of calcium and zinc, which is a consistent outcome in most Chinese populations around the world, has also persisted in this study population.

\section{Acknowledgements}

We wish to thank Ms Faliana Wing-Hang Lee for her involvement in setting up the Melbourne Chinese followup study and for her initial input. This project was supported by a research grant from the Palm Oil Research Institute of Malaysia.

\section{References}

1 Hsu-Hage BH, Ibiebele T, Wahlqvist ML. Food intakes of adult Melbourne Chinese. Aust. J. Public Health 1995; 19: 623-8.

2 Cashel K, English R, Bennett S, Berzins J, Brown G, Magnus P. National Dietary Survey of Adults: 1983. Canberra: Australian Government Publishing Service, 1986.

3 Curb JD, Marcus EB. Body fat and obesity in Japanese Americans. Am. J. Clin. Nutr. 1991; 53: 1552S-5S.

4 Poulter NR, Khaw KT, Mugambi M, Peart WS, Sever PS Migration-induced changes in blood pressure: a controlled longitudinal study. Clin. Exp. Pharmacol. Physiol. 1985; 12 211-6.

5 Salmond CE, Prior IA, Wessen AF. Blood pressure patterns and migration: a 14-year cohort study of adult Tokelauans. Am. J. Epidemiol. 1989; 130: 37-52.

6 Baghurst KI, Baghurst PA, Record SJ. Demographic and dietary profiles of high and low fat consumers in Australia. J. Epidemiol. Community Health 1994; 48: 26-32.

7 Glatthaar C, Welborn TA, Stenhouse NS, Garcia-Webb P. Diabetes and impaired glucose tolerance. A prevalence estimate based on the Busselton 1981 survey. Med. J. Aust. 1985; 143: 436-40.

8 Knekt P, Seppanen R, Jarvinen R, et al. Dietary cholesterol, fatty acids, and the risk of lung cancer among men. Nutr. Cancer 1991; 16: 267-75.

9 Posner BM, Cobb JL, Belanger AJ, et al. Dietary lipid predictors of coronary heart disease in men. The Framingham Study. Arch. Intern. Med. 1991; 151: 1181-7.

10 Willett WC. Diet and coronary heart disease. In: Willett WC, ed. Nutritional Epidemiology. New York: Oxford University Press, 1990; 341-79.

11 Hage BH-H. Food Habits and Cardiovascular Health Status in Adult Melbourene Chinese. Melbourne: Department of Medicine, Monash University, 1992.

12 Hage BH, Oliver RG, Powles JW, Wahlqvist ML. Telephone directory listings of presumptive Chinese surnames: an appropriate sampling frame for a dispersed population with characteristic surnames. Epidemiology 1990; 1: 405-8.

13 Hsu-Hage BH-H, Wahlqvist ML. A food frequency questionnaire for use in Chinese populations and its validation. Asia Pacific J. Clin. Nutr. 1992; 1: 211-23.

14 English R, Lewis J. Nutritional Values of Australian Food. Canberra: Australian Government Publishing Service, 1991.
15 Wang GY. Food Composition Table [in Chinese]. Beijing: People's Health Press, 1991.

16 Department of Science and Technology of Japan. Standard Japanese Food Composition Tables. Japan: Department of Science and Technology, 1997.

17 Tee SE, Noor MI, Azudin MN, Idris K. Nutritient Composition of Malaysia Foods. Malaysia: ASEAN Food Habits Project, 1988.

18 SAS Institute, Inc. SAS/STAT Software. Cary, NC: SAS Institute, Inc., 1997.

19 McLennan W, Podger A. National Nutrition Survey: Selected Highlights Australia 1995. Canberra: Australian Bureau of Statistics, 1997.

20 National Health and Medical Research Council (NHMRC). Dietary Guidelines for Australians. Canberra: Australian Government Publishing Service, 1992.

21 Webb K, Manderson L. Food habits and their influence on health. In: Reid J, Trompf P, eds. The Health of Immigrant Australia - A Social Perspective. Sydney: Harcourt Brace Jovanovich, 1990; 155-203.

22 Baghurst KI, Crawford D, Worsley A, et al. The Victorian Nutrition Survey: a profile of the energy, macronutrient and sodium intakes of the population. Community Health Stud. 1988; 12: 42-54.

23 Ruithauser I, Wahlqvist ML. Food intake patterns of Greek migrants to Melbourne in relation to duration of stay. Proc. Nutr. Soc. Aust. 1983; 8: 49-55.

24 Chen X, Wen Z, Lin H. Dietary fat consumption and noncommunicable chronic diseases in China. In: Proceedings of 2nd International Conference. Kuching, Malaysia: Asia Pacific Clinical Nutrition Society, 1998; 29.

25 Janus ED. Hong Kong Cardiovascular Risk Factor Prevalence Study, 1995-1996. Report, Hong Kong, 1997.

26 Food and Agriculture Organization/World Health Organization (FAO/WHO). Requirement of Vitamin A, Iron, Folate, and Vitamin $B_{12}$. Report of a joint FAO/WHO expert committee. FAO Food and Nutrition Series No. 23. Rome: FAO, 1989; 1-107.

27 Qu JB, Zhang ZW, Xu GF, et al. Urban-rural comparison of nutrient intake by adult women in Shandong Province, China. Toboku J. Exp. Med. 1997; 183: 21-36.

28 Tian HG, Nan Y, Hu G, et al. Dietary survey in a Chinese population. Eur. J. Clin. Nutr. 1995; 49: 26-32.

29 Zhang ZW, Qu JB, Moon CS, et al. Nutritional evaluation of women in urban areas in continental China. Tohoku J. Exp. Med. 1997; 182: 41-59.

30 Russell-Aulet M, Wang J, Thornton JC, Colt EW, Pierson RN Jr. Bone mineral density and mass in a cross-sectional study of white and Asian women. J. Bone Mineral Res. 1993; 8: 575-82.

31 Anderson JJ, Pollitzer WS. Ethnic and genetic differences in susceptibility to osteoporotic fractures. Adv. Nutr. Res. 1994; 9: $129-49$.

32 Arija V, Salas Salvado J, Fernandez-Ballart J, Cuco G, MartiHenneberg C. Food consumption, habits, and nutritional status of the population of Reus (VIII). Evolution of energy and nutrient intake from 1983 to 1993 [in Spanish]. Med. Clin. 1996; 106: 45-50.

33 Woo J, Leung SS, Ho SC, Sham A, Lam TH, Janus ED. Influence of educational level and marital status on dietary intake, obesity and other cardiovascular risk factors in Hong Kong Chinese population. Eur. J. Clin. Nutr. 1999; 53: $461-7$.

34 Zhang H. Melbourne Chinese Cohort Study - A Prospective Study of Food Habits and Health Risk. Melbourne: Monash University, 1999.

35 Zhang H, Hage BH-H, Wahlqvist ML. Changes in cardiovascular risk factors in Melbourne Chinese Cohort Study. Proc. Nutr. Soc. Aust. 1997; 21: 82. 